\title{
Analisis Tingkat Kognitif Soal Modul Pengayaan Kelas VIII Materi Persamaan Garis Lurus dan Sistem Persamaan Linear Dua Variabel Berdasarkan Taksonomi Bloom Revisi
}

\author{
Melvi Khairani, Agus Susanta, Nurul Astuty Yensy B
}

(C) 2021 JEMS (Jurnal Edukasi Matematika dan Sains)

This is an open access article under the CC-BY-SA license

(https://creativecommons.org/licenses/by-sa/4.0/) ISSN 2337-9049 (print), ISSN 2502-4671 (online)

\begin{abstract}
Abstrak:
Penelitian ini bertujuan untuk mengetahui sebaran tingkat kognitif soal - soal bab persamaan garis lurus dan sistem persamaan linear dua variabel pada modul pengayaan matematika kelas VIII semester 1 terbitan putra nugraha berdasarkan Taksonomi Bloom Revisi. Jenis penelitian ini adalah penelitian deskriptif dengan pendekatan kualitatif. Sumber data pada penelitian ini adalah soal - soal bab persamaan garis lurus dan sistem persamaan linear dua variabel pada modul pengayaan matematika kelas VIII semester 1 terbitan putra nugraha. Soal pada bab persamaan garis lurus terdiri dari 60 soal yang memuat soal dengan tingkat kognitif mengingat (C1) sebanyak 2 soal (3,33\%), memahami (C2) sebanyak 2 soal (3,33\%), mengaplikasikan (C3) sebanyak 56 soal $(93,34 \%)$ dan tidak memuat soal dengan tingkat kognitif menganalisis (C4), mengevaluasi (C5), dan mencipta (C6). Sedangkan soal pada bab sistem persamaan linear dua variabel terdiri dari 56 soal yang memuat soal dengan tingkat kognitif mengingat (C1) sebanyak 2 soal $(3,57 \%)$, memahami (C2) sebanyak 1 soal $(1,79 \%)$, mengaplikasikan (C3) sebanyak 49 soal $(87,50 \%)$, menganalisis (C4) sebanyak 4 soal $(7,14 \%)$ serta tidak memuat soal dengan tingkat kognitif mengevaluasi (C5), dan mencipta (C6).
\end{abstract}

Kata Kunci : Modul Pengayaan; Soal; Taksonomi Bloom; Tingkat Kognitif

\begin{abstract}
:
This research determines the distribution of the cognitive level of questions in the chapter on straight line equations and systems of linear equations two variables in the mathematics enrichment module for class VIII semester 1 published by Putra Nugraha based on Revised Bloom's Taxonomy. This type of research was descriptive research with a qualitative approach. Sources of data in this study were questions about the chapter on straight line equations and systems of linear equations two variables in the mathematics enrichment module for class VIII semester 1 published by Putra Nugraha. The questions in the straight-line equation chapter consist of 60 questions containing the cognitive level of remembering (C1) was 2 questions (3.33\%), understanding (C2) was 2 questions (3.33\%), applying (C3) was 56 questions (93.34\%) and didn't contain questions with cognitive levels of analyzing (C4), evaluating (C5), and creating (C6). While the questions in the systems of linear equations two variables chapter consist of 56 questions containing the cognitive level of remembering (C1) was 2 questions (3.57\%), understanding (C2) was 1 questions (1.79\%), applying (C3) was 49 questions $(87.50 \%)$, analyzing (C4) was 4 questions (7.14\%) and didn't contain questions with cognitive levels of evaluating (C5), and creating (C6).
\end{abstract}

Keywords : Enrichment Module, Question, Bloom Taxonomy, Cognitive Level.

\section{Pendahuluan}

Pendidikan yang menjadi salah satu aspek terpenting dalam kehidupan, telah memberikan sumbangsi besarnya dalam perkembangan Bangsa Indonesia. Pendidikan yang bangsa bergantung dari mutu sumber energi manusianya. Sehingga, penting untuk lembaga pemerintahan terus berupaya membetulkan pembelajaran yang ada, guna meningkatkan sumber energi manusia, sehingga cita-cita leluhur bangsa ialah mencerdaskan kehidupan bangsa Indonesia dapat terwujud.

Melvi Khairani, Universitas Bengkulu

melvikhairani11@gmail.com

Agus Susanta, Universitas Bengkulu

unibagus@yahoo.com

Nurul Astuty Yensy B, Universitas Bengkulu

nurulastutyyensy@unib.ac.id 
Matematika ialah salah satu cabang ilmu pengetahuan yang ikut memegang peranan berarti dalam dunia pendidikan. Bukan hanya dalam pertumbuhan dunia pendidikan, matematika berguna pula dalam pertumbuhan teknologi. Sehingga, kita perlu untuk menekuni matematika. Matematika juga merupakan mata pelajaran yang diajarkan disemua tingkat pendidikan dari tingkat Sekolah Dasar sampai Sekolah Menengah Atas serta Perguruan Tinggi juga terdapat mata kuliahnya. Tujuan dari pelajaran matematika pada Kurikulum 2013 Lampiran 3 Permendikbud Nomor. 58 ialah supaya siswa bisa menguasai konsep matematika, menerangkan keterkaitan antarkonsep, memakai konsep ataupun algoritma, secara luwes, akurat, efektif, serta tepat, dalam menyelesaikan pemecahan masalah (Kemendikbud, 2014).

Bersumber pada paparan tersebut, hingga bisa disimpulkan kalau pelajaran matematika sangat bermanfaat untuk siswa paling utama dalam membongkar permasalahan. Tetapi, pada realitasnya masih banyak siswa yang hadapi kesusahan dalam membongkar permasalahan matematika. Bisa dilihat dari capaian yang diperoleh siswa SMP Indonesia pada Tes Nasional bersumber pada informasi Puspendik (2018) mata pelajaran matematika senantiasa mendapatkan nilai rata-rata terendah dibanding mata pelajaran yang lain. Pada tahun 2017 nilai rata-rata UN SMP mata pelajaran matematika ialah 50,31. Pada tahun 2018 nilai rata-rata UN SMP mata pelajaran matematika hadapi penyusutan jadi 43,34 serta nilai rata-rata UN SMP mata pelajaran matematika tahun 2019 ialah sebesar 45,52. Rendahnya capaian siswa di mata pelajaran matematika, bukan hanya pada hasil UN namun juga pada Penilaian Akhir Semester (PAS). Rata- rata nilai PAS Ganjil Tahun Ajaran 2020/2021 yang didapatkan siswa Kelas VIII SMP 2 Kota Bengkulu pada mata pelajaran matematika ialah 50,96.

Penilaian Akhir Semester (PAS) kelas VIII yang dilakukan oleh SMP Negeri 02 Kota Bengkulu pada mata pelajaran matematika terdiri dari 5 Bab, 2 Bab diantaranya yaitu Persamaan Garis Lurus (PGL) dan Sistem Persamaan Linear Dua Variabel (SPLDV). Kedua bab tersebut merupakan materi yang cukup sulit, karena berdasarkan sebaran jawaban PAS, siswa banyak menjawab salah pada kedua materi tersebut. Selain itu, nilai ulangan harian yang diperoleh siswa juga tergolong belum mencukupi KKM. Rata-rata nilai ulangan harian yang didapat siswa kelas VIII SMP Negeri 02 Kota Bengkulu pada materi PGL dan SPLDV hanya sebesar 69.

Banyak aspek yang menjadi pemicu rendahnya kemampuan siswa pada pelajaran matematika, salah satunya ialah fasilitas serta prasarana belajar siswa. Bahan ajar ialah penunjang fasilitas serta prasarana belajar untuk siswa sangat dibutuhkan guna menolong siswa selama proses belajar. Bahan ajar merupakan suatu bahan yang digunakan oleh pendidik dalam melakukan aktivitas belajar mengajar yang tersusun secara sistematis baik tertulis ataupun tidak tertulis (Yezita, Rosha \& Yerizon, 2012).

Modul merupakan bahan ajar tulis yang bertujuan membantu siswa belajar mandiri tanpa ataupun dengan bantuan guru, sehingga modul wajib berisi mengenai petunjuk belajar, kompetensi yang ingin dicapai, materi pelajaran, data pendukung, latihan soal, petunjuk pengerjaan, penilaian serta balikan terhadap hasil penilaian (Prastowo dalam Yuberti, 2014). Salah satu bentuk modul ialah modul pengayaan. Modul ini merupakan salah satu bahan ajar yang diterapkan disekolah dalam menolong siswa belajar dirumah, khususnya pada masa pandemi Covid-19 sekarang ini. Pemakaian modul pengayaan sudah diterapkan di SMP Negeri 02 Kota Bengkulu dan sebagian SMP yang lain yang terdapat di Kota Bengkulu guna mendukung aktivitas belajar mengajar di rumah. Untuk di SMP Negeri 02 Kota Bengkulu menggunakan modul pengayaan terbitan Putra Nugraha.

Soal-soal pada modul pengayaan, digunakan untuk mengukur penguasaan siswa dalam memahami materi. Soal-soal tersebut tidak hanya menjadi latihan bagi siswa, tetapi juga menjadi pedoman guru SMP Negeri 02 Kota Bengkulu dalam pembuatan soal Penilaian 
Tengah Semester (PTS) dan Penilaian Akhir Semester (PAS). Sehingga soal-soal tersebut haruslah memiliki variasi tingkat kesukaran yang seimbang, mulai dari tingkat mudah hingga tingkat sulit. Soal-soal yang ada pada modul pengayaan matematika kelas VIII semester 1 terbitan Putra Nugraha yang digunakan di SMP Negeri 02 Kota Bengkulu belum diketahui tingkat kogitifnya.

Soal-soal yang ada pada modul pengayaan matematika kelas VIII semester 1 terbitan Putra Nugraha terdiri dari 3 bagian soal, yaitu soal pendalaman, soal uji kompetensi dan soal perbaikan. Soal pendalaman bertujuan untuk membantu siswa dalam mempersiapkan kematangan mereka dalam memahami materi (Utami \& Nurgiyantoro, 2016). Capaian siswa, dalam mengerjakan soal, bisa dijadikan tolok ukur untuk melihat sebatas mana kemampuan mereka dalam kompetensi bahan ajar yang sudah diterima. Soal uji kompetensi ialah satu contoh alat ukur yang dimanfaatkan untuk mengetahui kemampuan siswa (Sa'idah, Yulistianti, \& Megawati, 2019). Salah kemampuan tersebut ialah kemampuan berfikir level tinggi siswa. Kemampuan berfikir level tinggi sangat penting karena ada sebagian poin yang menjadi standar kompetensi lulusan sekolah menengah (Susanti, Trapsilasiwi, \& Kurniati, 2015). Untuk mencapai kemampuan berfikir tingkat tinggi dalam pembelajaran matematika, siswa perlu untuk mengerjakan soal yang membutuhkan pemikiran untuk C4-menganalisis, C5-mengevaluasi, dan C6-mencipta (Paicasari, Sarjana, Kurniawan \& Azmi, 2021). Pembelajaran perbaikan berbentuk pengkajian ulang soal-soal pelajaran yang telah lalu (Masithoh \& Abdah, 2019). Ketiga bagian soal pada modul pengayaan ini belum diketahui tingkat kogitifnya.

Tingkat kognitif soal dapat dilihat berdasarkan Taksonomi Bloom yang disampaikan pertama kali oleh Benjamin S. Bloom pada tahun 1956 yang kemudian diperbaiki oleh Anderson dan Krathwohl pada tahun 1990. Taksonomi Bloom Revisi digunakan dalam menentukan tingkat kognitif soal, karena ada penggabungan pengetahuan serta pemikiran baru dalam suatu kerangka pengelompokkan tujuan pendidikan. Taksonomi Bloom Revisi diklasifikasikan menjadi tiga dimensi, yaitu dimensi kognitif, dimensi afektif dan dimensi psikomotorik. Tingkat kesukaran soal ini ditinjau berdasarkan dimensi kognitif. Dimensi kognitif terbagi menjadi 6 tingkatan yaitu, mengingat (C1), memahami (C2), menerapkan (C3), menganalisis (C4), mengevaluasi (C5) dan mencipta (C6) (Anderson \& Krathwohl, 2010).

Analisis tentang butir soal pada bahan ajar, pernah dilakukan oleh beberapa peneliti. Diantaranya, penelitian yang dilakukan oleh Nursyaidah (2020) pada soal buku siswa matematika kelas VIII kurikulum 2013 berdasarkan ranah kognitif dalam Taksonomi Bloom. Penelitian serupa juga dilakukan oleh Fauziyyah (2020) yang meneliti soal - soal buku ajar matematika kelas VIII ditinjau dari revisi Taksonomi Bloom. Dari beberapa penelitian yang pernah dilakukan terhadap bahan ajar matematika, terdapat pembagian yang kurang merata disetiap aspek kognitifnya, serta masih rendahnya jumlah soal berpikit tingkat tinggi.

Berdasarkan paparan diatas, dilakukanlah penelitian mengenai "Analisis Tingkat Kognitif Soal Modul Pengayaan Kelas VIII Materi Persamaan Garis Lurus dan Sistem Persamaan Linear Dua Variabel Berdasarkan Taksonomi Bloom Revisi". Tujuan dari penelitian ialah untuk mengetahui sebaran tingkat kognitif soal pada Bab Persamaan Garis Lurus dan Sistem Persamaan Linear Dua Variabel Berdasarkan Taksonomi Bloom Revisi. Penelitian ini bermanfaat sebagai acuan dalam memilih soal - soal yang tepat untuk diberikan kepada siswa, sehingga dapat mengukur tingkat kemampuan siswa, serta dapat juga digunakan sebagai acuan untuk penyempurnaan bahan ajar berikutnya, terutama untuk modul pengayaan kelas VIII terbitan putra nugraha berdasarkan Taksonomi Bloom Revisi. 


\section{Metode}

Jenis penelitian ialah penelitian deskriptif dengan pendekatan kualitatif, yaitu penelitian yang menuturkan, menganalisis dan mengintepretasikan pemecahan masalah yang ada sekarang berdasarkan data dengan menggunakan metode yang lebih menekankan pada aspek pemahaman secara mendalam terhadap suatu permasalahan. Subjek penelitian ini adalah soal-soal yang ada pada Modul Pengayaan Matematika Kelas VIII Semester 1 yang ditulis oleh Tezar Arnenda dan diterbitkan oleh Putra Nugraha pada materi Persamaan Garis Lurus dan Sistem Persamaan Linear Dua Variabel. Prosedur penelitian ini adalah sebagai berikut:

1. Mengumpulkan soal pada Modul Pengayaan Matematika Kelas VIII Semester 1 Terbitan Putra Nugraha.

2. Menyelesaikan soal pada Modul Pengayaan Matematika Kelas VIII Semester 1 Terbitan Putra Nugraha.

3. Mendeskripsikan setiap tingkat kognitif yang muncul dalam menyelesaikan soal.

4. Menganalisis tingkat kognitif yang muncul dalam menyelesaikan soal berdasarkan Taksonomi Bloom Revisi.

5. Menghitung jumlah soal untuk setiap tingkat kognitif.

6. Menganalisis persentase soal untuk masing - masing tingkat kognitif. Kemudian, membandingkan persentase soal yang didapat dengan proporsi soal yang mendukung capaian kompetensi dasar.

7. Melakukan uji keabsahan data.

8. Membuat kesimpulan dan saran.

Teknik pengumpulan data yang dipergunakan yaitu metode dokumentasi yang merupakan teknik dalam mengumpulkan data dengan cara mencatat data yang ada (Ahyar, Andriani, \& Sukmana, 2020). Data tersebut dapat berasal dari catatan, transkrip, buku, surat kabar, majalah, prasasti, notulen rapat, lengger, agenda, dan lain sebagainya (Siyoto \& Sodik, 2015: 77).

Instrumen penelitian yang digunakan adalah lembar klasifikasi tingkat kognitif soal dan lembar validasi kesesuaian tingkat kognitif soal. Indikator penentuan tingkat kognitif soal berdasarkan Taksonomi Bloom Revisi dapat dilihat pada Tabel 1:

Tabel 1. Indikator Penentuan Tingkat Kognitif Soal

\begin{tabular}{|c|c|}
\hline $\begin{array}{c}\text { Dimensi } \\
\text { Proses Kognitif }\end{array}$ & Indikator Soal \\
\hline \multirow{12}{*}{$\begin{array}{l}\text { Mengingat } \\
\quad(\mathrm{C} 1)\end{array}$} & a. Kategori Mengenali \\
\hline & 1. Mengidentifikasikan sifat/ciri/bentuk/konsep dari PGL dan SPLDV \\
\hline & $\begin{array}{l}\text { 2. Mengidentifikasikan informasi yang disajikan oleh soal untuk } \\
\text { menyelesaikan permasalahan mengenai persamaan garis lurus dan sistem } \\
\text { persamaan linear dua variabel }\end{array}$ \\
\hline & $\begin{array}{l}\text { 3. Mengidentifikasikan variabel, koefisien, dan konstanta dari persamaan } \\
\text { yang diberikan soal }\end{array}$ \\
\hline & b. Kategori Mengingat \\
\hline & 1. Menyebutkan pengertian atau bentuk umum dari PGL dan SPLDV \\
\hline & 2. Menyatakan hubungan antara gradien dengan kedudukan dua garis. \\
\hline & $\begin{array}{l}\text { 3. Menyebutkan atau menuliskan rumus untuk mencari kemiringan atau } \\
\text { gradien }\end{array}$ \\
\hline & $\begin{array}{l}\text { 4. Menyebutkan atau menuliskan rumus untuk mencari persamaan garis } \\
\text { lurus }\end{array}$ \\
\hline & $\begin{array}{l}\text { 5. Menyebutkan atau menuliskan metode yang dapat digunakan untuk } \\
\text { mencari penyelesaian dari sistem persamaan }\end{array}$ \\
\hline & Menyebutkan pengertian dari himpunan penyelesaian \\
\hline & Menyebutkan pengertian dari variabel, koefisien dan konstanta \\
\hline
\end{tabular}




\begin{tabular}{|c|c|}
\hline $\begin{array}{c}\text { Dimensi } \\
\text { Proses Kognitif }\end{array}$ & Indikator Soal \\
\hline \multirow[t]{7}{*}{$\begin{array}{l}\text { Memahami } \\
\text { (C2) }\end{array}$} & $\begin{array}{l}\text { a. Kategori Menafsirkan } \\
\text { Mengubah kalimat atau soal cerita mengenai persamaan garis lurus dan } \\
\text { sistem persamaan garis lurus menjadi model matematikanya. }\end{array}$ \\
\hline & $\begin{array}{l}\text { b. Kategori Mencontohkan } \\
\text { 1. Memberikan contoh yang berkaitan dengan bentuk PGL dan SPLDV } \\
\text { 2. Memberikan beberapa nilai } x \text { yang menjadi penyelesaian dari persamaan }\end{array}$ \\
\hline & $\begin{array}{l}\text { c. Kategori Mengklasifikasi } \\
\text { 1. Mengelompokkan sifat/ciri/bentuk/konsep dari PGL dan SPLDV sesuai } \\
\text { dengan informasi yang diberikan soal } \\
\text { 2. Mengategorikan absis dan ordinat dari titik yang diketahui pada soal }\end{array}$ \\
\hline & $\begin{array}{l}\text { d. Kategori Merangkum } \\
\text { Merangkum informasi yang diberikan soal sehingga membentuk suatu } \\
\text { persamaan garis lurus atau sistem persamaan linear dua variabel. }\end{array}$ \\
\hline & $\begin{array}{l}\text { e. Kategori Menyimpulkan } \\
\text { Menyimpulkan informasi yang diperoleh dari soal untuk menyelesaiakan } \\
\text { permasalahan yang berhubungandengan PGL atau SPLDV }\end{array}$ \\
\hline & $\begin{array}{l}\text { f. } \text { Kategori Membandingkan } \\
\text { Menentukan hubungan antara dua informasi atau lebih yang diperoleh } \\
\text { dari soal terkait dengan sifat/ciri/bentuk/konsep dari PGL atau SPLDV }\end{array}$ \\
\hline & $\begin{array}{l}\text { g. Kategori Menjelaskan } \\
\text { 1. Memuat sebab-akibat antar informasi yang diberikan soal mengenai PGL } \\
\text { atau SPLDV. } \\
\text { 2. Menjelaskan metode yang digunakan dalam menyelesaikan permasalahan } \\
\text { pada sistem persamaan linear dua variabel. }\end{array}$ \\
\hline
\end{tabular}

Mengaplikasikan a. Kategori Mengeksekusi

1. Menentukan titik potong untuk menggambar grafik persamaan garis lurus pada bidang koordinat Kartesius dan menentukan himpunan penyelesaian dari persamaan serta menggambar himpunan penyelesain persamaan linear dua variabel.

2. Menerapkan rumus untuk mencari gradien dari suatu persamaan garis lurus atau menerapkan rumus untuk mencari persamaan garis lurus.

3. Mensubstitusikan titik yang diketahui ke persamaan garis lurus untuk mencari salah satu nilai absis atau ordinat dan mensubstitusikan absis atau ordinat ke persamaan.

4. Menentukan gradien atau kedudukan dua garis dengan menggunakan hubungan antara gradien dengan kedudukan antara dua garis.

5. Menerapkan satu metode atau lebih untuk mencari penyelesaian dari SPLDV.

6. Menentukan persamaan yang tegak lurus atau sejajar dengan persamaan yang diberikan soal.

7. Mensubstitusikan himpunan penyelesaian ke persamaan.

8. Menerapkan sifat - sifat kesetaraan untuk menyelesaikan persamaan.

9. Menerapkan operasi aljabar untuk mengubah bentuk persamaan garis.

b. Kategori Mengimplementasikan

1. Menerapkan prosedur yang belum diketahui untuk menyelesaikan permasalahan yang berkenaan dengan PGL dan SPLDV.

2. Memodifikasi variabel pada persamaan linear dua variabel untuk mencari himpunan penyelesaian.

3. Menentukan persamaan yang diketahui himpunan penyelesaiannya.

\begin{tabular}{ccc}
$\begin{array}{c}\text { Menganalisis } \\
\text { (C4) }\end{array}$ & a. & Kategori Membedakan \\
& Memilih informasi yang relevan pada soal untuk menyelesaikan masalah \\
\cline { 3 - 3 }
\end{tabular}




\begin{tabular}{|c|c|}
\hline $\begin{array}{c}\text { Dimensi } \\
\text { Proses Kognitif } \\
\end{array}$ & Indikator Soal \\
\hline & PGL dan SPLDV. \\
\hline & $\begin{array}{l}\text { b. Kategori Mengorganisasi } \\
\text { 1. Menggabungkan/ mengaitkan beberapa konsep matematika, untuk } \\
\text { mencari penyelesaian dari permasalahan PGL dan SPLDV. } \\
\text { 2. Mengaitkan beberapa informasi yang diberikan pada soal dengan konsep } \\
\text { matematika untuk menyelesaikan permasalahan pada PGL dan SPLDV. }\end{array}$ \\
\hline & $\begin{array}{l}\text { Kategori Mengatribusikan } \\
\text { Menentukan maksud dari soal berdasarkan sudut pandang pembaca } \\
\text { untuk menyelesaikan permasalahan mengenai PGL dan SPLDV. }\end{array}$ \\
\hline \multirow[t]{2}{*}{$\begin{array}{l}\text { Mengevaluasi } \\
\quad \text { (C5) }\end{array}$} & $\begin{array}{l}\text { a. } \quad \text { Kategori Memeriksa } \\
\quad \text { Membuktikan sebuah pernyataan mengenai PGL dan SPLDV. }\end{array}$ \\
\hline & $\begin{array}{l}\text { Kategori Mengkritik } \\
\text { Menemukan kesalahan dari suatu pernyataan mengenai PGL dan SPLDV. }\end{array}$ \\
\hline \multirow[t]{3}{*}{$\begin{array}{l}\text { Mencipta } \\
\quad \text { (C6) }\end{array}$} & $\begin{array}{l}\text { a. Kategori Merumuskan } \\
\text { Memuat formula/ide/hipotesis/ dugaan untuk menyelesaikan masalah } \\
\text { mengenai PGL dan SPLDV. }\end{array}$ \\
\hline & $\begin{array}{l}\text { b. Kategori Merencanakan } \\
\text { Membuat rencana untuk menyelesaikan permasalahan mengenai PGL } \\
\text { dan SPLDV dengan memodifikasi prosedur. }\end{array}$ \\
\hline & $\begin{array}{l}\text { Kategori Memproduksi } \\
\text { Melaksanakan prosedur yang telah direncanakan untuk menyelesaikan } \\
\text { permasalahan mengenai PGL dan SPLDV. }\end{array}$ \\
\hline
\end{tabular}

Teknik analisis data untuk menghitung persentase tingkat kognitif dengan menggunakan rumus berikut:

Dengan:

$$
P_{i}=\frac{N_{i}}{N} \times 100 \%
$$

$P_{i}=$ Persentase banyaknya soal yang dikategorikan berdasarkan tingkat Taksonomi Bloom Revisi, (i = tingkat proses kognitif C1, C2, C3, C4, C5, dan C6)

$N_{i}=$ Jumlah soal yang terkategorikan dalam tingkat proses kognitif berdasarkan Taksonomi Bloom Revisi, (i = tingkat proses kognitif C1, C2, C3, C4, C5, dan C6)

$N=$ Jumlah semua soal yang diamati

Teknik analisis data untuk menghitung kesesuaian korelasi, dapat menggunakan uji Spearman Rank. Uji ini bertujuan untuk melihat ada atau tidak hubungan diantara variabel, besar - kecilnya keeratan hubungan antarvariabel, arah hubungan antarvariabel, dan menguji keberartian hubungan antarvariabel. Spearman Rank digunakan untuk data berskala ordinal. Koefisien korelasi Spearman Rank dapat dihitung dengan menggunakan SPSS atau menggunakan rumus korelasi Spearman Rank yaitu :

Dengan:

$$
\rho=1-\frac{6 \sum b_{i}^{2}}{n\left(n^{2}-1\right)}
$$

$\rho=$ Koefisien korelasi Spearman Rank; $b_{i}^{2}=$ Selisih peringkat setiap data; $n=$ Jumlah data

Data yang diperoleh dari hasil analisis tingkat kognitif soal dimisalkan menjadi $\mathrm{C} 1=1$, $\mathrm{C} 2=2, \mathrm{C} 3=3, \mathrm{C} 4=4, \mathrm{C} 5=5$, dan $\mathrm{C} 6=6$ yang kemudian datanya diolah dengan menggunakan SPSS. 
Pedoman interpretasi koefisien korelasi Spearman Rank dapat dilihat pada Tabel 2:

Tabel 2. Interpretasi Koefisien Korelasi Spearman Rank

\begin{tabular}{ll}
\hline \multicolumn{1}{c}{ Koefisien Korelasi } & \multicolumn{1}{c}{ Interpretasi } \\
\hline $0,00 \leq \rho<0,20$ & Hubungan sangat lemah (diabaikan, dianggap tidak ada) \\
$0,20 \leq \rho<0,40$ & Hubungan rendah \\
$0,40 \leq \rho<0,70$ & Hubungan sedang/cukup \\
$0,70 \leq \rho<0,90$ & Hubungan kuat \\
$0,90 \leq \rho \leq 1,00$ & Hubungan sangat kuat/tinggi \\
\hline
\end{tabular}

Keterangan:

Modifikasi $r=\rho=$ Koefisien Korelasi Spearman Rank

Apabila hasil koefisien korelasi analisis tingkat kognitif soal berada direntang lebih dari sama dengan 0,40 atau saat hubungan antara peneliti dengan teman sejawat sedang/kuat/sangat kuat, maka tidak perlu dilakukan analisis ulang.

\section{Hasil dan Pembahasan}

\section{Deskripsi Sebaran Tingkat Kognitif Soal}

Hasil analisis tingkat kognitif soal ini berupa persentase untuk setiap tingkatan kognitif. Berikut adalah persentase tingkat kognitif soal yang disajikan untuk setiap bab:

\section{Bab 4 Persamaan Garis Lurus}

Bab Persamaan Garis Lurus terdiri dari 60 soal. Soal - soal pada bab ini terdiri dari Soal Pendalaman, Soal Uji Kompetensi dan Soal Perbaikan. Soal Pendalaman pada Bab Persamaan Garis Lurus didominasi oleh soal dengan tingkat kognitif (C3) "Mengaplikasikan" sebanyak 17 soal dengan persentase sebesar 94,44\%. Sementara untuk soal dengan tingkat kognitif (C2) "Memahami", (C4) "Menganalisis", (C5) "Mengevaluasi", dan (C6) "Mencipta" tidak ada. Soal Uji Kompetensi pada Bab Persamaan Garis Lurus didominasi oleh soal dengan tingkat kognitif (C3) "Mengaplikasikan" sebanyak 30 soal dengan persentasenya yaitu 96,77\%. Sedangkan untuk soal dengan tingkat kognitif (C2) "Memahami", (C4) "Menganalisis, (C5) "Mengevaluasi", dan (C6) "Mencipta" tidak ada. Soal perbaikan pada Bab Persamaan Garis Lurus, hanya terdiri dari 2 tingkat kognitif, yaitu soal pada tingkat kognitif (C2) "Memahami" dan (C3) "Mengaplikasikan", yang didominasi oleh soal dengan tingkat kognitif (C3) "Mengaplikasikan" sebesar 81,82\%.

Sebaran tingkat kognitif soal pada Bab Persamaan Garis Lurus secara keseluruhan, dapat dilihat pada Tabel 3:

Tabel 3. Jumlah dan Persentase Soal Bab Persamaan Garis Lurus

\begin{tabular}{lcc}
\hline \multicolumn{1}{c}{ Tingkat Kognitif } & Banyak Soal & Persentase \\
\hline C1 (Mengingat) & 2 & $3,33 \%$ \\
C2 (Memahami) & 2 & $3,33 \%$ \\
C3 (Mengaplikasikan) & 56 & $93,34 \%$ \\
C4 (Menganalisis) & 0 & $0 \%$ \\
C5 (Mencipta) & 0 & $0 \%$ \\
C6 (Mencipta) & 0 & $0 \%$ \\
Jumlah & 60 & $100 \%$ \\
\hline
\end{tabular}

Berdasarkan Tabel 3, soal - soal yang ada pada Bab Persamaan Garis Lurus hanya memiliki 3 tingkat kognitif dari 6 tingkat kognitif Taksonomi Bloom revisi yaitu C1 (Mengingat), C2 (Memahami) dan C3 (Mengaplikasikan). Soal - soal pada bab ini didominasi oleh soal dengan tingkat kognitif C3 (Mengaplikasikan). 


\section{Bab 5 Sistem Persamaan Linear Dua Variabel}

Soal - soal pada Bab Sistem Persamaan Linear Dua Variabel terdiri dari 56 soal dengan 3 bagian soal, yaitu soal pendalaman, soal uji kompetensi dan soal perbaikan. Soal pendalaman didominasi oleh soal dengan tingkat kognitif (C3) "Mengaplikasikan" sebanyak 13 soal dengan persentase sebesar 86,67\%. Sementara, tidak ada soal dengan tingkat kognitif (C2) "Memahami", (C4) "Menganalisis", (C5) "Mengevaluasi", (C6) "Mencipta". Soal uji kompetensi didominasi oleh soal dengan tingkat kognitif (C3) "Mengaplikasikan" sebanyak 27 soal dengan persentasenya yaitu sebesar 87,09\%. Sedangkan persentase untuk soal dengan tingkat kognitif (C1) "Mengingat", (C5) "Mengevaluasi", dan (C6) "Mencipta" sebesar $0 \%$. Soal perbaikan pada bab ini hanya terdiri dari soal dengan tingkat kognitif (C3) "Mengaplikasikan" dan (C4) "Menganalisis" yang didominasi oleh soal dengan tingkat kognitif (C3) "Mengaplikasikan", yaitu sebesar 90\%.

Secara keseluruhan sebaran tingkat kognitif soal pada Bab Sistem Persamaan Linear Dua dapat dilihat pada Tabel 4:

Tabel 4. Jumlah dan Persentase Soal Bab Sistem Persamaan Linear Dua Variabel

\begin{tabular}{lcc}
\hline \multicolumn{1}{c}{ Tingkat Kognitif } & $\begin{array}{c}\text { Banyak } \\
\text { Soal }\end{array}$ & Persentase \\
\hline C1 (Mengingat) & 2 & $3,57 \%$ \\
C2 (Memahami) & 1 & $1,79 \%$ \\
C3 (Mengaplikasikan) & 49 & $87,50 \%$ \\
C4 (Menganalisis) & 4 & $7,14 \%$ \\
C5 (Mencipta) & 0 & $0 \%$ \\
C6 (Mencipta) & 0 & $0 \%$ \\
Jumlah & 56 & $100 \%$ \\
\hline
\end{tabular}

Dilihat dari Tabel 4, soal - soal pada bab Sistem Persamaan Linear Dua Variabel memiliki 4 tingkat kognitif dari 6 tingkat kognitif Taksonomi Bloom revisi yaitu C1 (Mengingat), C2 (Memahami), C3 (Mengaplikasikan), dan C4 (Menganalisis). Bab ini didominasi oleh soal - soal dengan tingkat kognitif C3 (Mengaplikasikan).

Kesesuaian Analisis Tingkat Kognitif Soal dengan Teman Sejawat

Paparan kesesuaian analisis tingkat kognitif soal antara peneliti dengan teman sejawat yang dipaparkan perbab.

Bab 4 Persamaan Garis Lurus

Perbedaan hasil analisis tingkat kognitif berdasarkan Taksonomi Bloom Revisi yang dilakukan antara peneliti dengan teman sejawat I dan II pada Bab Persamaan Garis Lurus, dari 60 soal yang diklasifikasikan tingkat kognitifnya, dapat dilihat pada Tabel 5:

Tabel 5. Perbedaan Tingkat Kognitif Soal Antara Peneliti dengan Teman Sejawat Pada Bab Persamaan Garis Lurus

\begin{tabular}{lccc}
\hline \multicolumn{1}{c}{ Butir Soal } & Peneliti & Teman Sejawat I & Teman Sejawat II \\
\hline UK Bagian B Nomor 6 & C1 & C2 & C2 \\
Perbaikan Bagian B Nomor 3a & C2 & C1 & C1 \\
Perbaikan Bagian B Nomor 3b & C3 & C3 & C1 \\
Perbaikan Bagian B Nomor 5 & C2 & C3 & C3 \\
\hline
\end{tabular}

Berdasarkan Tabel 5, terdapat 3 butir soal yang berbeda tingkat kognitifnya antara peneliti dengan teman sejawat I atau persentase perbedaan analisis tingkat kognitif soal antara peneliti dengan teman sejawat I yaitu sebesar 5\%. Perbedaan analisis tingkat kognitif soal antara peneliti dengan teman sejawat II ada 4 soal atau persentase perbedaan analisis 
tingkat kognitif soal antara peneliti dengan teman sejawat II yaitu sebesar 6,67\%. Perbedaaan analisis tingkat kognitif soal antara teman sejawat I dan teman sejawat II ada 1 butir soal atau perbedaan analisis tingkat kognitif soal antara teman sejawat I dengan teman sejawat II yaitu sebesar 1,67\%.

Korelasi analisis tingkat kognitif soal Bab Persamaan Garis Lurus antara peneliti dengan teman sejawat I diperoleh 0,868 yang artinya hubungan keduanya kuat. Koefisien korelasi antara peneliti dengan teman sejawat II diperoleh 0,735 yang artinya hubungan keduanya kuat, sedangkan koefisien korelasi antara teman sejawat I dengan teman sejawat II diperoleh 0,853 yang artinya hubungan keduanya kuat.

\section{Bab 5 Sistem Persamaan Linear Dua Variabel}

Hasil analisis tingkat kognitif soal Bab Sistem Persamaan Linear Dua Variabel yang terdiri dari 56 soal, yang dilakukan oleh peneliti, memiliki beberapa perbedaan dengan teman sejawat I dan teman sejawat II. Beberapa perbedaan tersebut dapat dilihat pada Tabel 6:

Tabel 6. Perbedaan Tingkat Kognitif Soal Antara Peneliti dengan Teman Sejawat Pada Bab Sistem Persamaan Linear Dua Variabel

\begin{tabular}{lccc}
\hline \multicolumn{1}{c}{ Butir Soal } & Peneliti & Teman Sejawat I & Teman Sejawat II \\
\hline UK Bagian B Nomor 1 & C3 & C3 & C2 \\
UK Bagian C Nomor 3b & C4 & C3 & C3 \\
UK Bagian C Nomor 4 & C4 & C3 & C4 \\
Perbaikan Bagian A Nomor 1 & C3 & C3 & C2 \\
\hline
\end{tabular}

Dari Tabel 6 dapat dilihat bahwa, terdapat 2 butir soal yang berbeda tingkat kognitifnya antara peneliti dengan teman sejawat I dengan persentase perbedaannya sebesar $3,57 \%$. Perbedaan analisis tingkat kognitif soal antara peneliti dengan teman sejawat II ada 3 soal dengan persentase perbedaan sebesar 5,36\%. Serta, terdapat 3 soal yang berbeda tingkat kognitifnya antara teman sejawat I dan teman sejawat II atau persentase perbedaannya sebesar $5,36 \%$.

Hasil koefisien korelasi analisis tingkat kognitif antara peneliti dengan teman sejawat I pada bab ini yaitu sebesar 0,849 yang artinya hubungan antara peneliti dengan teman sejawat I yaitu kuat, sedangkan koefisien korelasi antara peneliti dengan teman sejawat II diperoleh 0,817 yang artinya hubungan antara peneliti dengan teman sejawat II yaitu kuat dan koefisien korelasi antara teman sejawat I dengan teman sejawat II diperoleh 0,801 yang artinya hubungan antara teman sejawat I dengan teman sejawat II keduanya yaitu kuat.

\section{Deskripsi Analisis Tingkat Kognitif Soal}

Beberapa contoh deskripsi analisis tingkat kognitif soal, disajikan pada penjelasan di bawah ini,

1. Soal Pendalaman Bagian A Nomor 6

Gambar 1. Soal

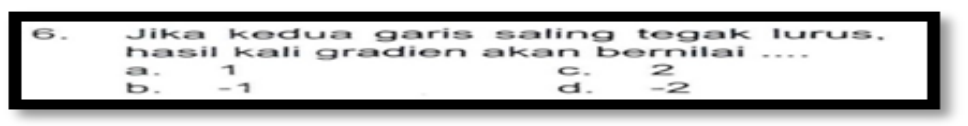

Pendalaman Bagian A Nomor 6 Bab Persamaan Garis Lurus

Analisis Soal: 
Untuk mengetahui hasil kali gradien dua garis yang saling tegak lurus, maka:

Siswa harus mengingat kembali (C1) materi mengenai hubungan gradien garis dan kedudukan dua garis jika kedua garis tersebut saling tegak lurus. Menyatakan hubungan antara gradien dengan kedudukan dua garis termasuk ke dalam kategori mengingat (C1). Sehingga soal ini tergolong pada tingkat kognitif (C1) "Mengingat".

2. Soal

$$
\begin{aligned}
& \text { 3. Diketahui garis k memiliki gradien } \frac{1}{2} \text {. Tentukan gradien garis ! jika garis tersebut: } \\
& \text { a. sejajar dengan garis } k \text {, b. tegak lurus dengan garis } k \text {. } \\
& \text { Jawab: }
\end{aligned}
$$

\section{Gambar 2. Soal Perbaikan Bagian B Nomor 3a Bab Persamaan Garis Lurus}

Analisis Soal:

Untuk mencari gradien dari garis $l$ yang sejajar dengan garis $k$, maka:

1. Siswa harus mengingat kembali (C1) hubungan antara gradien dengan kedudukan garis yang saling sejajar. Hubungannya yaitu, saat dua garis saling sejajar maka gradiennya sama atau $m_{1}=m_{2}$;

2. Siswa menyimpulkan (C2) bahwa gradien garis kedua adalah $\frac{1}{2^{\prime}}$ karena kedua garis yang sejajar memiliki gradien yang sama.

Menyimpulkan informasi untuk mencari gradien garis kedua yang sejajar dengan garis pertama, termasuk ke dalam kategori menyimpulkan (C2). Maka, soal ini tergolong pada tingkat kognitif (C2) "Memahami".

3. Soal Pendalaman Bagian B Nomor 3

3. Tentukan himpunan penyelesaian dari sistem persamaan $-3 x+2 y=-11$ dan $4 x-5 y=3$ dengan metode eliminasi.

Jawab: .

\section{Gambar 3. Soal Pendalaman Bagian B Nomor 3 Bab Sistem Persamaan Linear Dua Variabel}

Analisis Soal:

Untuk mencari himpunan penyelesaian pada soal ini, maka:

1. Siswa harus mengidentifikasi (C1) terlebih dahulu, informasi apa saja yang diberikan soal;

2. Siswa menjelaskan (C2) cara mencari himpunan penyelesaian dengan metode eliminasi;

3. Siswa menerapkan (C3) metode eliminasi untuk mencari himpunan penyelesaian dengan, mengeleminasi variabel $y$ untuk mencari nilai $x$, didapat nilai $x$ adalah 7 dan mengeliminasi variabel $x$ untuk mencari nilai $y$, didapat nilai $y$ adalah 5 .

Menerapkan salah satu metode untuk mencari penyelesaian masalah pada soal termasuk ke dalam kategori mengeksekusi (C3). Maka, soal ini tergolong pada tingkat kognitif (C3) "Mengaplikasikan". 
4. Soal Uji Kompetensi Bagian A Nomor 14

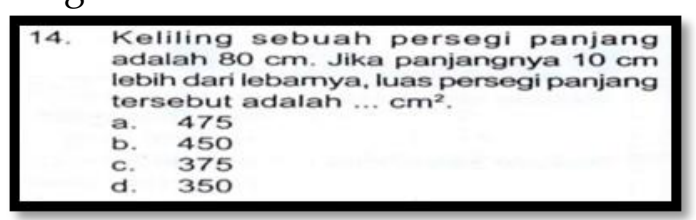

Gambar 4. Soal Uji Kompetensi Bagian A Nomor 14 Bab Sistem Persamaan Linear Dua Variabel

Analisis Soal:

Untuk mencari luas persegi panjang pada soal, maka:

1. Siswa harus mengidentifikasikan (C1) informasi yang diberikan soal dan mengingat kembali (C1) rumus keliling dan luas persegi panjang;

2. Siswa mengubah (C2) bentuk soal cerita yang diberikan menjadi bentuk model matematikanya, sehingga sistem persamaan yaitu $2 p+2 l=80$ dan $p=10+l$;

3. Siswa menjelaskan (C2) metode yang digunakan untuk mencari penyelesaian masalah;

4. Siswa menerapkan (C3) metode substitusi dengan mensubsitusikan $p=10+l$ ke persamaan $2 p+2 l=80$ menggantikan variabel $p$, sehingga didapat $l$ persegi panjang adalah $15 \mathrm{~cm}$. Setelah itu, siswa mensubstitusikan nilai $l$ yang didapat ke persamaan $2 p+2 l=80$, didapat nilai $p=25 \mathrm{~cm}$;

5. Siswa menerapkan (C3) rumus luas persegi panjang dengan mengunakan nilai $p$ dan $l$ yang didapat.

Soal ini, telah menggabungkan beberapa konsep matematika, yaitu konsep keliling dan luas persegi panjang dengan konsep sistem persamaan linear dua variabel. sehingga soal ini termasuk ke dalam kategori mengorganisasi (C4). Maka, soal ini tergolong pada tingkat kognitif (C4) "Menganalisis".

\section{Pembahasan}

Bab 4 Persamaan Garis Lurus

Soal - soal pada Bab Persamaan Garis Lurus belum sepenuhnya memuat kompetensi dasar. Salah satunya yang belum termuat yaitu menginterpretasikan grafik yang dihubungkan dengan masalah kontekstual dan menyelesaikan masalah kontekstual yang berkaitan dengan fungsi linear sebagai persamaan garis lurus. Soal - soal pada Bab Persamaan Garis Lurus terdiri dari 3 bagian, yaitu soal pendalaman, soal uji kompetensi dan soal perbaikan.

Soal - soal pendalaman pada bab ini, bertujuan untuk mengetahui pemahaman siswa mengenai materi menentukan gradien garis dan hubungan gradien garis dengan kedudukan dua garis. Menentukan berdasarkan KKO terdapat pada tingkat kognitif mengaplikasikan (C3). Sehingga, soal pendalaman Bab Persamaan Garis Lurus pada modul pengayaan yang diteliti, telah sesuai dengan teori, karena soal pendalaman pada bab ini didominasi oleh soal dengan tingkat kognitif mengaplikasikan (C3). Soal uji kompetensi pada modul seharusnya memuat soal dengan tingkat kognitif menganalisis (C4), mengevaluasi (C5) dan mencipta (C6). Tetapi, soal uji kompetensi pada bab ini tidak terdapat soal dengan tingkat kognitif menganalisis (C4), mengevaluasi (C5) dan mencipta (C6). Sehingga, soal uji kompetensi pada Bab Persamaan Garis Lurus belum memenuhi kriteria soal uji kompetensi. 
Tingkat kognitif soal yang mendominasi soal perbaikan sama dengan tingkat kognitif soal yang mendominasi soal pendalaman dan soal uji kompetensi, yaitu didominasi oleh soal dengan tingkat kognitif mengaplikasikan (C3). Berdasarkan teori, soal perbaikan merupakan soal yang digunakan untuk mengkaji ulang soal - soal pelajaran yang telah lalu (Masithoh \& Abdah, 2019). Oleh karena itu, soal perbaikan berisi soal - soal yang pernah dikerjakan pada soal pendalaman dan soal uji kompetensi, sehingga soal perbaikan juga didominasi oleh soal dengan tingkat kognitif mengaplikasikan (C3) sama halnya dengan soal pendalaman dan soal uji kompetensi.

Secara keseluruhan soal - soal pada bab persamaan garis lurus, belum tersebar secara merata tingkat kognitifnya. Soal - soal bab ini didominasi oleh soal dengan tingkat kognitif mengaplikasikan (C3) sebanyak 56 soal dari 60 soal. Sedangkan soal dengan tingkat kognitif menganalisis (C4), mengevaluasi (C5), dan mencipta (C6) tidak ada.

\section{Bab 5 Sistem Persamaan Linear Dua Variabel}

Hasil dari penelitian yang dilakukan, menunjukkan soal - soal pada Bab Sistem Persamaan Linear Dua Variabel telah memenuhi dan sesuai dengan kompetensi dasar. Kompetensi Dasar menjelaskan sistem persamaan linear dua variabel termasuk ke dalam tingkat kognitif memahami (C2) dan menyelesaikan masalah sistem persamaan linear dua variabel termasuk ke dalam tingkat kognitif mengaplikasikan (C3). Soal - soal pada bab ini juga telah menggunakan masalah - masalah kontekstual. Soal - soal pada Bab Sistem Persamaan Linear Dua Variabel terdiri dari 3 bagian, yaitu soal pendalaman, soal uji kompetensi, dan soal perbaikan.

Soal pendalaman bertujuan agar siswa memahami metode penyelesaian dari sistem persamaan linear dua variabel, sehingga untuk memahami masing - masing metode, siswa harus menerapkan metode - metode tersebut, berdasarkan indikator penentuan tingkat kognitif soal, menerapkan metode penyelesaian termasuk ke dalam tingkat kognitif mengaplikasikan (C3). Sehingga berdasarkan teori, dapat disimpulkan bahwa soal pendalaman Bab Persamaan Garis Lurus pada modul pengayaan yang diteliti telah sesuai dengan teori, yaitu didominasi oleh soal dengan tingkat kognitif mengaplikasikan (C3).

Soal uji kompetensi pada Bab Sistem Persamaan Linear Dua Variabel telah terdapat soal dengan tingkat kognitif menganalisis (C4), tetapi hanya sebanyak 4 soal, sementara tidak ada soal dengan tingkat kognitif mengevaluasi (C5) dan mencipta (C6). Seharusnya soal uji kompetensi telah memuat soal dengan tingkat kognitif mengevaluasi (C5) dan mencipta (C6). Soal perbaikan pada bab ini, sama seperti soal pendalaman dan uji kompetensi yang juga didominasi oleh soal dengan tingkat kognitif mengaplikasikan (C3). Pada soal perbaikan, juga terdapat soal dengan tingkat kognitif menganalisis (C4) sebanyak 1 soal. Berdasarkan teori, soal perbaikan sama halnya dengan soal pendalaman dan soal uji kompetensi, dan soal perbaikan pada $\mathrm{Bab}$ ini juga memuat soal dengan tingkat kognitif menganalisis (C4), sama seperti soal uji kompetensi yang juga memuat soal dengan tingkat kognitif menganalisis (C4).

Secara keseluruhan soal - soal pada Bab Sistem Persamaan Linear Dua Variabel, belum tersebar secara merata tingkat kognitifnya. Soal - soal pada bab ini didominasi oleh soal dengan tingkat kognitif mengaplikasikan (C3) sebanyak 49 soal. Sedangkan soal dengan tingkat kognitif mengevaluasi (C5) dan mencipta (C6) tidak ada. 


\section{Kesesuaian Analisis Tingkat Kognitif Soal dengan Teman Sejawat}

Paparan mengenai perbedaan analisis tingkat kognitif soal antara peneliti dengan teman sejawat I dan teman sejawat II yang dipaparkan perbab.

\section{Bab 4 Persamaan Garis Lurus}

Perbedaan analisis tingkat kognitif soal, dijelaskan secara lebih rinci yaitu sebagai berikut: Soal Uji Kompetensi Bagian B Nomor 6

Gradien garis yang persamaannya $y=4$ adalah

\section{Gambar 5. Soal Uji Kompetensi Bagian B Nomor 6 Bab Persamaan Garis Lurus}

Peneliti mengklasifikasikan soal ini ke dalam tingkat kognitif mengingat (C1), karena siswa harus mengingat kembali gradien garis yang sejajar dengan sumbu $x$. Sedangkan teman sejawat I dan teman sejawat II mengklasifikasikan soal ini ke dalam tingkat kognitif memahami (C2), karena menurut teman sejawat I, untuk mencari gradien garis $y=4$, siswa harus menjelaskan gradien garis yang memuat $y$ sejajar dengan sumbu $x$, dimana gradien garis yang sejajar sumbu $x$ adalah 0 . Sementara menurut teman sejawat II untuk mencari gradien garis $y=4$ siswa harus mengubah persamaan menjadi bentuk $y=m x+c$.

Bab 5 Sistem Persamaan Linear Dua Variabel

Perbedaan analisis tingkat kognitif soal, dijelaskan secara lebih rinci yaitu sebagai berikut: Soal Uji Kompetensi Bagian B Nomor 1

Penyelesaian dari $3(2-x)+9=2 x-5$ adalah $\ldots \ldots$

\section{Gambar 6. Soal Uji Kompetensi Bagian B Nomor 1 Bab Sistem Persamaan Linear Dua Variabel}

Peneliti mengklasifikasikan soal ini ke dalam tingkat kognitif mengaplikasikan (C3), karena siswa menerapkan sifat - sifat kesetaraan untuk mencari penyelesaian dari persamaan yang diberikan. Teman sejawat I juga mengklasifikasikan soal ini ke dalam tingkat kognitif mengaplikasikan (C3). Sedangkan, teman sejawat II mengklasifikasikan soal ini pada tingkat kognitif memahami (C2), karena berdasarkan pandangan teman sejawat II, soal ini hanya menuntut siswa mengoperasikan persamaan untuk menemukan nilai $x$.

\section{Simpulan}

Berdasarkan hasil dan pembahasan mengenai analisis tingkat kognitif soal modul pengayaan matematika kelas VIII semester 1 pada materi persamaan garis lurus dan sistem persamaan linear dua variabel, dapat disimpulkan bahwa soal-soal Bab Persamaan Garis Lurus pada modul pengayaan kelas VIII semester 1 terbitan putra nugraha yang terdiri dari 60 soal, setelah dilakukan analisis tingkat kognitifnya didapat sebaran tingkat kognitif soal 
pada bab ini memuat soal dengan tingkat kognitif mengingat (C1) sebanyak 2 soal (3,33\%), memahami (C2) sebanyak 2 soal (3,33\%), mengaplikasikan (C3) sebanyak 56 soal $(93,34 \%)$ dan tidak memuat soal dengan tingkat kognitif menganalisis (C4), mengevaluasi (C5), dan mencipta (C6). Soal - soal pada bab ini didominasi oleh soal dengan tingkat kognitif mengaplikasikan (C3). Berdasarkan sebaran tingkat kognitif soal pada bab ini, maka dapat diketahui bahwa soal pada bab ini belum bervariasi.

Soal-soal Bab Sistem Persamaan Linear Dua Variabel pada modul pengayaan kelas VIII semester 1 terbitan putra nugraha terdiri dari 56 soal. Setelah dilakukan analisis terhadap soal - soal pada bab ini, didapat sebaran tingkat kognitifnya yaitu, soal dengan tingkat kognitif mengingat (C1) sebanyak 2 soal (3,57\%), memahami (C2) sebanyak 1 soal $(1,79 \%)$, mengaplikasikan (C3) sebanyak 49 soal (87,50\%), menganalisis (C4) sebanyak 4 soal $(7,14 \%)$ dan tidak memuat soal dengan tingkat kognitif mengevaluasi (C5), dan mencipta (C6). Berdasarkan sebaran tingkat kognitif soal pada bab ini, maka dapat diketahui bahwa soal pada bab ini belum bervariasi.

\section{Daftar Rujukan}

Ahyar, H., Andriani, H., \& Sukmana, D. J. (2020). Buku Metode Penelitian Kualitatif $\mathcal{E}$ Kuantitatif (H. Abadi (ed.); 1st ed.). Yogyakarta: CV. Pustaka Ilmu.

Anderson, L. W., \& Krathwohl, D. R. (2010). Kerangka Landasan Untuk Pembelajaran, Pengajaran, dan Asesmen Revisi Taksonomi Pendidikan Bloom (2010th ed.). Terjemahan oleh Agung Prihantoro. 2010. Yogyakarta: Pustaka Pelajar.

Fauziyyah, H. N. (2020). Ananalisis Soal-Soal Buku Ajar Matematika Kelas VIII Ditinjau Dari Revisi Taksonomi Bloom. In Skripsi. Universitas Muhammadiyah Surakarta: Surakarta.

Kemendikbud. (2014). Peraturan Menteri Pendidikan Dan Kebudayaan Republik Indonesia Nomor 58 Tahun 2014. Jakarta: Kementerian Pendidikan dan Kebudayaan.

Masithoh, D. D., \& Abdah, Z. A. El. (2019). Program Perbaikan dan Pengayaan. Umsida Repository.

Nursyaidah. (2020). Analisis Soal Uji Kompetensi Pada Buku Siswa Matematika Kelas VIII Kurikulum 2013 Berdasarkan Ranah Kognitif Dalam Taksonomi Bloom. In Skripsi. Institut Agama Islam Negeri (IAIN) Salatiga: Salatiga.

Paicasari, N. N. Y., Sarjana, K., Kurniawan, E., \& Azmi, S. (2021). Analisis soal uji kompetensi pada buku paket matematika siswa kurikulum 2013 untuk SMP / MTs kelas VII semester 1 ditinjau dari taksonomi Bloom. 1(2), 99-105.

Puspendik. (2018). Hasil UN Mata Ujian Matematika 2017-2018-2019.pdf. Jakarta: Puspendik Kemendikbud.

Sa'idah, N., Yulistianti, H. D., \& Megawati, E. (2019). Analisis Instrumen Tes Higher Order Thinking Matematika SMP. Jurnal Pendidikan Matematika, 13(1), 41-54.

Siyoto, S., \& Sodik, M. A. (2015). Dasar Metodologi Penelitian (Ayup (ed.); 1st ed.). Yogyakarta: Literasi Media Publishing.

Susanti, N. Y., Trapsilasiwi, D., \& Kurniati, D. (2015). Analisis Tingkat Kognitif Uji Kompetensi pada Buku Sekolah Elektronik (BSE) Matematika SMP/MTs Kelas VII Kurikulum 2013 Berdasarkan Taksonomi Bloom. Kreano, Jurnal Matematika KreatifInovatif, 6(1), 67. 
Utami, S. Y., \& Nurgiyantoro, B. (2016). Kualitas Soal dan Daya Serap Tes Pendalaman Materi UN Bahasa Indonesia SMP di Gunung Kidul. Jurnal Diksi, 24(1), 52-62.

Yezita, E., Rosha, M., \& Yerizon. (2012). Mengkonstruksi Pengetahuan Siswa Pada Materi Segitiga dan Segiempat Menggunakan Bahan Ajar InterAktif Matematika Berbasis Konstruktivisme. Jurnal Pendidikan Matematika, Vol 1(No 1), 54-59.

Yuberti. (2014). Teori Pembelajaran dan Pengembangan Bahan Ajar Dalam Pendidikan. Bandar Lampung: Anugrah Utama Raharja (AURA) ANGGOTA IKAPI. 